\title{
The Impact of using Mining Pit Water on Flotation Performance of a Sedimentary Phosphate ore
}

\author{
M.D Hlahane, W. Nheta and M.E Makhatha
}

\begin{abstract}
The pit water from one of the sedimentary phosphates mine in the Western Cape (South Africa) is not suitable for flotation due to contamination and poor understanding of its properties. Pit water samples were collected at the mining pit area during different periods, submitted to a comprehensive chemical analysis and compared with municipal tap water. It was found that the pit water stream was not acidic but rather basic with a pH measure of 8.09 which was close to the tap water at 7.98. Electrical conductivity (EC) of the pit water was 60.3 vs $20.7 \mathrm{mS} / \mathrm{m}$ of tap water, Calcium carbonate concentrations of pit water was at $95 \mathrm{vs} 66 \mathrm{mg} / \mathrm{L}$ of tap water and total dissolved solids (TDS) of the pit water was $332 \mathrm{mg} / \mathrm{L}$ vs $144 \mathrm{mg} / \mathrm{L}$ of the tap water. There were elevated concentrations of Sodium $(\mathrm{Na})$ and Chlorine $(\mathrm{Cl})$ on the pit water. With pre-treatment, Pit water has high potential in the flotation of phosphates minerals.
\end{abstract}

Keywords. - Froth flotation, pit water, water quality, waste management.

\section{INTRODUCTION}

A sedimentary phosphate mine in the Western Cape (South Africa) pumps at least 10ML per day to dewater the upper aquifer using boreholes in order to safely mine the phosphate ore body. The boreholes are connected in a closed system and the aquifer water is recharged into the ground water approximately $2-3 \mathrm{~km}$ from the mining area. It is estimated that at least 5 percent of the pumped aquifer water escapes the boreholes and enters the mining pit area as seepage water, herein referred to as pit water (PW) which is exposed to atmospheric conditions and possible hydrocarbons from mining equipment and therefore cannot be recharged to ground water.

Generally, it would be an ideal situation to use pit water in the process and reduce the usage of municipal water but there is inadequate knowledge and understanding of the impact the pit water quality would have on flotation performance. Flotation results of previous studies have shown that the quality of the process water in general, and recirculating water, can have adverse effect on the flotation selectivity of complex sulphide minerals, mainly due to one or more of the following factors, residual xanthates and their oxidation products [1].

Other studies have found that the flotation recovery of

Morake Dawid Hlahane, University of Johannesburg, South Africa. W. Nheta and M.E Makhatha, University of Johannesburg, South Africa phosphate minerals is inversely proportional to the hardness of the water that is used in grinding, conditioning and flotation. It is further alluded that elevated levels of water hardness results in more silica reporting to the phosphate concentrate. These partial contradictions of the influence of water quality on the processing of sedimentary phosphate ore, provides challenges for the phosphate mine in relation to the use of mining pit water on its flotation process.

There are two major processes adopted by the phosphate industry to enrich phosphate minerals by froth flotation: Direct flotation process and reverse flotation process. In direct froth flotation process, the value minerals (apatite and apatite derivatives) are rendered hydrophobic, floated and collected in the froth layer whereas in the reverse flotation process, phosphate-bearing minerals are depressed allowing the gangue minerals to float [2].

There is a gap of knowledge regarding the impact and influence of pit water to flotation response of individual geological horizons of the sedimentary phosphate mine in the Western Cape (South Africa). This study seeks to understand the impact of the pit water quality to downstream flotation performance.

\section{MATERIALS AND METHODS}

\section{A. Pit water chemical analysis}

Pit water samples were collected at the mining pit area during different periods and submitted for a comprehensive chemical analysis and compared with municipal tap water. The two pit water samples were collected when there was mining activity around the pit area, namely pit water 1 (PW1) and when there was inactivity around the pit, pit water 2 (PW2).

The samples were analyzed for $\mathrm{pH}$, Total Dissolved Solids (TDS), Total Suspended Solids (TSS), Electrical conductivity (Eh) and other analytes. The analysis was conducted by an accredited laboratory using automated photometric analysis for water chemistry and determination of dissolved metals by ICP-OES method. There are many parameters that influences the quality of water, for the purpose of this study, elements such as total suspended solids (TSS), total dissolved solids (TDS), electrical conductivity (EC), Iron (Fe) and typical contaminants such as amongst others Magnesium (Mg), Sulphate (SO4), Calcium (Ca), Potassium (K) and Sodium (Na) were monitored. All the parameters are critical each or combined 
have a direct influence on the quality of water.

\section{B. Sedimentary phosphate ore characterization}

Sedimentary phosphate core samples were submitted for determination of bulk mineralogical composition and optimal liberation using X-Ray diffraction method and Scanning Electron Microscopy.

\section{Froth flotation and reagents}

Batch bench scale flotation tests were conducted using a laboratory D12 Denver flotation machine. Froth flotation tests and reagent suite used for the bench scale tests followed the already developed split-circuit flowsheet. The flotation approach for the tests was Reverse-flotation and the reagent used for all the tests was CustAmine 1607, which was added and conditioned after each flotation stage. CustAmine 1607 (Amine) is recommended for cationic collector for flotation (silica flotation).

The split circuit consist of the fines (212/20 microns) and coarse (425/212microns) circuits both following reverse flotation. Both float feed samples were prepared using ball milling and screening to produce the required feed size fraction. Fines flotation circuit (212/20 microns), primarily involved 3-4 stages of flotation. Coarse flotation circuit (425/212 microns) followed a similar procedure as the fine's flotation circuit. For each tests the concentrates, tailings products were filtered, dried, weighed and prepared for chemical analysis.

\section{RESULTS AND DISCUSSION}

\section{A. Mining Pit water chemical analysis}

Table 1 shows chemical composition of both pit and tap water samples submitted for analysis. The results herein are expected to aid in decision making in relation to water quality and its impact to downstream processing.

\begin{tabular}{|c|c|c|c|}
\hline \multirow{2}{*}{ Elements } & \multicolumn{3}{|c|}{ Concentration } \\
\hline & Pit water 1 (As is) & Pit water 2 (As is $)$ & Tap Water ** \\
\hline $\mathrm{pH}$ & 8,09 & 7,68 & 7,98 \\
\hline Electrical Conductivity ( $\mathrm{mS} / \mathrm{m}$ as EC) & 60,3 & 44,3 & 20,73 \\
\hline Total Phosphorous (mg/Las TP) & 5,73 & 1,3 & notreported \\
\hline Phosphate $\left(\mathrm{mg} / \mathrm{Las} \mathrm{PO}_{4}\right)$ & 0,087 & 0,526 & notreported \\
\hline Sodium (mg/Las Na) & 84,4 & 70,1 & 9,59 \\
\hline Potass ium (mg/Las $\mathrm{K}$ ) & 2,47 & 2,25 & 3,27 \\
\hline Cal cium (mg/Las Ca) & 27,3 & 18,9 & 17,21 \\
\hline Magnesium (mg/Las Mg) & 6,45 & 6,29 & 6,61 \\
\hline $\operatorname{Iron}(\mathrm{mg} / \mathrm{L}$ as $\mathrm{Fe})$ & $-0,004$ & $-0,004$ & $18,38(\mathrm{um} / \mathrm{L}$ as $\mathrm{Fe}$ ) \\
\hline Aluminium (mg/Las Al) & $-0,002$ & $-0,002$ & 28,77 (um/Las Al) \\
\hline Chloride (mg/Las Cl) & 93,9 & 90,5 & 10,78 \\
\hline Sulphate (mg/Las SOA $)$ & 38,4 & 29 & 14,63 \\
\hline Nitrate $\left(\mathrm{mg} / \mathrm{L}\right.$ as $\left.\mathrm{NO}_{3}\right)$ & 0,735 & $-0,194$ & 0,48 \\
\hline Total Suspended Solids (mg/L as TSS) & 682 & $-4,5$ & notreported \\
\hline Chemical Oxygen Demand ( $\mathrm{mg} / \mathrm{L}$ as COD) & 55,7 & 73,9 & notreported \\
\hline Total Dissolved Solids (mg/Las TDS) & 332 & 259 & 144,46 \\
\hline Hardness $\left(\mathrm{mg} / \mathrm{Las}_{\mathrm{CaCO}}\right)$ & 95 & 73 & 65,91 \\
\hline Silica (mg/Las Si) & 0,225 & 4,19 & notreported \\
\hline
\end{tabular}

\section{B. $\quad$ H measurements of pit water samples}

The $\mathrm{pH}$ measurements for both pit water samples were above 7 as shown in Table 1, indicating that the pit water samples were not acidic but basic. Under normal conditions (room temperature) the $\mathrm{pH}$ of pure water is expected to be neither acidic nor basic but rather neutral with a $\mathrm{pH}$ of 7 . Where possible, flotation is carried out in an alkaline medium as most collectors, including xanthates, are stable under these conditions, and corrosion of cells, pipework, etc., is minimized [3].

According to [4], $\mathrm{pH}$ may enhance collector attachment to the mineral surface. Changing the $\mathrm{pH}$ of the system can chemically alter the surface chemistry of the minerals in the slurry by changing the surface charges. In acidic conditions, most minerals will have a positive charge and in alkaline conditions, a negative charge. Pit water samples herein analyzed had a $\mathrm{pH}$ value that falls within the alkalinity range. It is critical that $\mathrm{pH}$ is controlled within reasonable limits since it has a critical effect to flotation. It can possibly affect the surface chemistry of the minerals and it could also possibly influence the attraction of collectors to the mineral surfaces.

\section{Electrical Conductivity (EC)}

Electrical Conductivity (EC) of water is its ability to conduct an electric current. Salts or other chemicals that dissolve in water can break down into positively and negatively charged ions. EC and Total Dissolved Solids (TDS) are correlated and EC's ability depends on dissolved ion concentrations, ionic strength, and temperature of measurements. The dissolved ion concentration is usually measured as TDS [5].

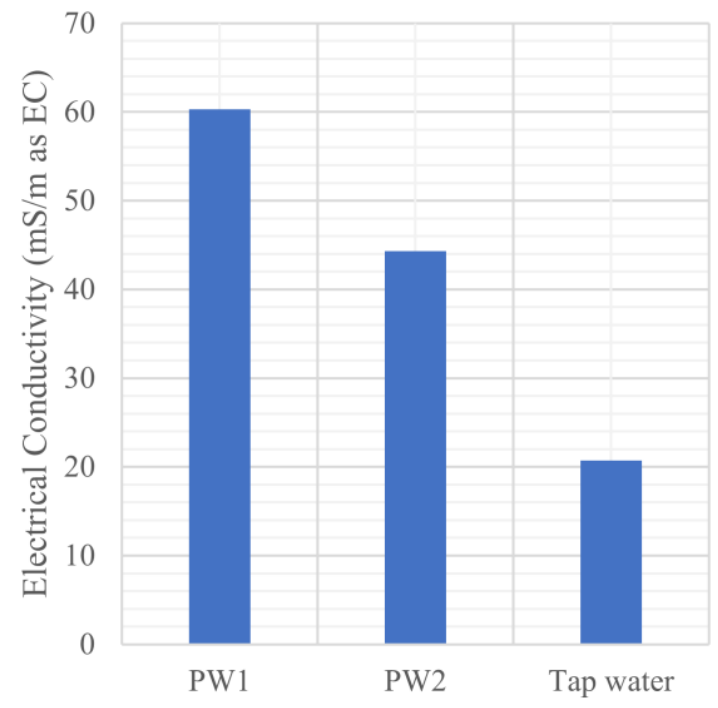

Fig.1: Pit water electrical conductivity (EC)

Figure 1 shows that EC of PW1 and PW2 samples were 60 and $44 \mathrm{mS} / \mathrm{m}$ consecutively against $20,7 \mathrm{mS} / \mathrm{m}$ of tap water. Indicating that there are more concentrations of ions in the pit water samples than tap water. When the two pit water samples are compared, the measure of EC for PW1 is slightly higher than that of PW2 as expected, which according to [6] could be resulting from the assertion that conductivity in water is affected by the presence of inorganic dissolved solids such as chloride, nitrate, sulfate, and phosphate anions or sodium, magnesium, calcium, iron, and aluminum cations (ions that carry a positive charge) [6]. 
In the Platinum Group Metals (PGM) flotation, in general, the higher the concentrations of ions in solution the higher its conductivity. Reference [1] showed that conductivity influenced PGM flotation, the lowest conductivity resulted in the highest concentrate recoveries. The conductivity of the water was further found to improve concentrate grade while reducing the recovery.

\section{Pit water hardness and Total Dissolved Solids (TDS)}

Figure 2 below shows that PW1 hardness was slightly higher at $95 \mathrm{mg} / \mathrm{L} \mathrm{CaCO}_{3}$, when compared to PW2 at $73 \mathrm{mg} / \mathrm{L} \mathrm{CaCO}_{3}$ and tap water at $65,91 \mathrm{mg} / \mathrm{L} \mathrm{CaCO}_{3}$.

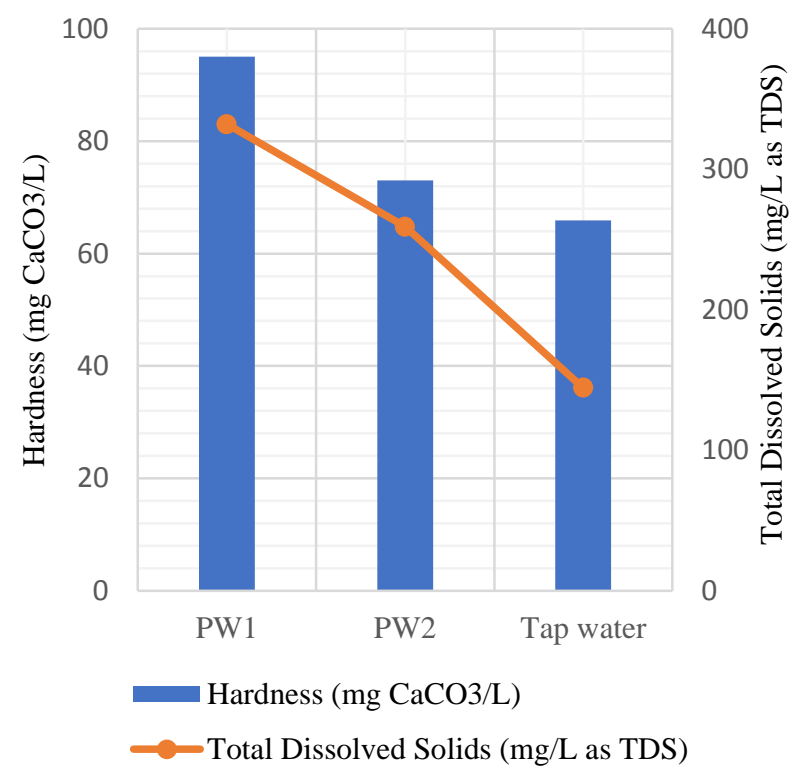

Fig.2: Hardness (mg/L as $\left.\mathrm{CaCO}_{3}\right)$ and TDS

Reference [7] asserts that water containing calcium carbonate at concentrations below $60 \mathrm{mg} / \mathrm{l}$ is generally considered as soft; $60-120 \mathrm{mg} / \mathrm{l}$, moderately hard; $120-180$ $\mathrm{mg} / \mathrm{l}$, hard and more than $180 \mathrm{mg} / \mathrm{l}$, very hard [8]. Based on the aforesaid ranges, both pit water samples herein analyzed could be considered to be moderately hard.

A similar trend can be observed as expected for TDS. According to [9], many parameters may be used to measure the deterioration of water quality and one very important parameter is total dissolved solids (TDS). Reference [9] further asserts that an increase in TDS beyond acceptable levels can have a significant impact on municipal, industrial, and agricultural use of water. TDS for PW1 and PW2 were 332 and $259 \mathrm{mg} / \mathrm{L}$ respectively when compared to $144 \mathrm{mg} / \mathrm{L}$ of the tap water.

Reference [10] argues that high dissolved solids (TDS) such as calcium sulfate in process water and recycle water are considered to have detrimental impact on selective flotation of desired minerals. In some sulphide mineral flotations, the recycled water contains high concentrations of $\mathrm{Ca}^{2+}$ and $\mathrm{SO}_{4}{ }^{2-}$ ions which exceed the solubility limit of gypsum. It is speculated that the gypsum would crystallize on mineral surfaces, resulting in reduced flotation sensitivity and recovery [10]. It is from this works that the pre-treatment of pit water for the sedimentary phosphate mine seem inevitable.

\section{E. Pit water Total Suspended Solids (TSS)}

Table 2 shows that TSS for PW1 was significantly higher at $682 \mathrm{mg} / \mathrm{L}$ than when there was no activity around the mining area.

TABLE II: TSS FOR PIT WATER SAMPLES.

\begin{tabular}{lcccc}
\hline Water Samples & Sampling & Analysis & TSS & Pit Area \\
\hline Pit Water unfiltered Batch 1 & Jul-18 & Jul-18 & 682 & Active \\
\hline Pit Water unfiltered Batch 2 & Jan-19 & Jan-19 & $-4,5$ & Inactive \\
\hline Tap Water & April (2018-2019) & - & - & - \\
\hline
\end{tabular}

It could be construed that when there's no activity around the pit area the pit water should be expected to have very insignificant suspended solids. It is important to mention that the period of inactivity was rather prolonged and unsustainable.

\section{F. Pit water Sodium ( $\mathrm{Na}$ ) and Chloride $(\mathrm{Cl})$ content}

Figure 3 shows that Sodium for PW1 and PW2 were 84,4 $\mathrm{mg} / \mathrm{L}$ and $70,1 \mathrm{mg} / \mathrm{L}$ respectively when compared to $9,6 \mathrm{mg} / \mathrm{L}$ for tap water. The chloride content of the Pit water samples ranged between $91-94 \mathrm{mg} / \mathrm{L}$ when compared to that of tap water at $10,8 \mathrm{mg} / \mathrm{L}$.

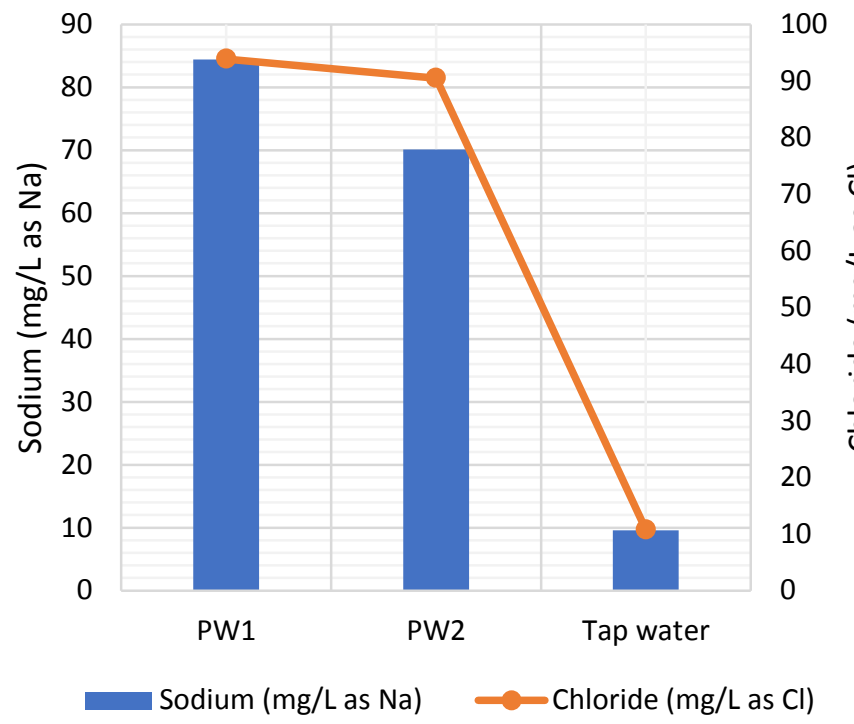

Fig. 3: Sodium (Na) and Chlorine $(\mathrm{Cl})$ content

Previous studies amongst others by Mullaney, et al. (2007) argues that Sodium and chloride are the most abundant ions present in the atmosphere above the oceans, and atmospheric deposition of chloride and sodium from the oceans is highest along coastal areas [11]. The pit water samples herein referred is primarily the seepage from groundwater. Reference [12] asserts that historical researchers have shown that $\mathrm{NaCl}$ depressed the flotation of chalcocite in Hallimond tube if the process was carried without a frother [12].

More work is required to understand the effects of $\mathrm{NaCl}$ to the flotation of sedimentary phosphate ore. 
Pit water Calcium (Ca) and Magnesium (Mg) content

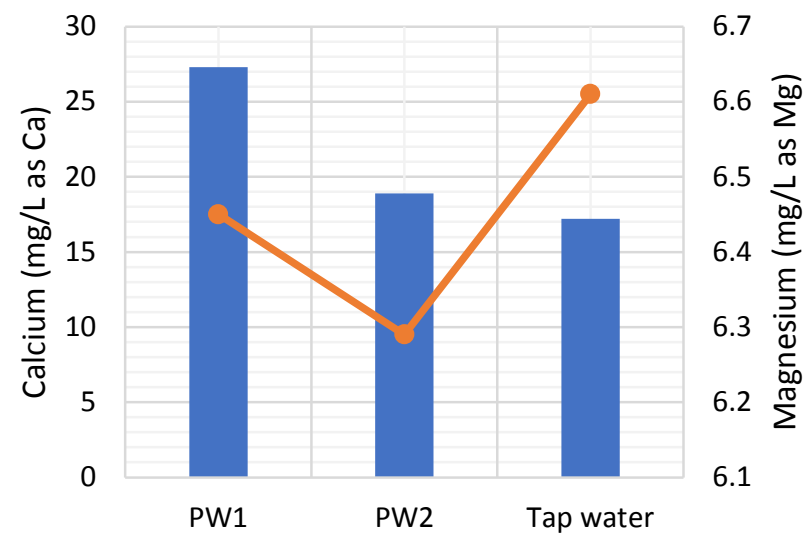

Calcium (mg/L as Ca) $\longrightarrow$ Magnesium (mg/L as Mg)

Fig. 4: Calcium and Magnesium content

Figure 4 show that PW1 has slightly higher level of Calcium content (27.3 mg/L) as compared to PW2 (18.9 mg/L) and tap water $(17.2 \mathrm{mg} / \mathrm{L})$. Reference [12] found that flotation of Phosphate ores with fatty acids (anionic collector) requires the removal of $\mathrm{Mg}^{2+}$ and $\mathrm{Ca}^{2+}$ ions if seawater is used in flotation [12]. The use of fatty acids is primarily used for the Crago process which in essence is direct flotation followed by reverse flotation. When the sedimentary phosphate mine considers adopting direct-reverse circuit over reverse-reverse flotation, the removal of $\mathrm{Mg}^{2+}$ and $\mathrm{Ca}^{2+}$ ions should be prioritized. Magnesium level of tap water was higher than both pit water samples.

\section{G. Sedimentary phosphate ore characterization}

The sedimentary phosphate deposit is estimated to be approximately 5million years old and comprises of apatite and quartz.

TABLE III: BULK MINERAL COMPOSITION OF THE SEDIMENTARY PHOSPHATE ORE [13]

\begin{tabular}{|c|c|c|}
\hline Mineral & Formula & Relative Abundance \\
\hline Quartz & $\mathrm{SiO}_{2}$ & $x \times x$ \\
\hline Apatite & $\mathrm{Ca}_{5}\left(\mathrm{PO}_{4}, \mathrm{CO}_{3}\right)_{3} \mathrm{~F}$ & $x x$ \\
\hline Crandallite & $\mathrm{CaAl}_{3}\left(\mathrm{PO}_{4}\right)_{2}(\mathrm{OH})_{5} \bullet\left(\mathrm{H}_{2} \mathrm{O}\right)$ & $\checkmark$ \\
\hline K-feldspar & $\mathrm{KAISi}_{3} \mathrm{O}_{8}$ & $\checkmark$ \\
\hline Zircon & $\mathrm{ZrSiO}_{4}$ & $\checkmark$ \\
\hline Rutile & $\mathrm{TiO}_{2}$ & $\checkmark$ \\
\hline Pentlandite & $(\mathrm{Fe}, \mathrm{Ni})_{9} \mathrm{~S}_{8}$ & $\checkmark$ \\
\hline Pyrite & $\mathrm{FeS}_{2}$ & $\checkmark$ \\
\hline Fe-oxide/hydroxide & $\mathrm{FeOOH} / \mathrm{Fe}_{2} \mathrm{O}_{3}$ & $\checkmark$ \\
\hline Clay (kaolinite) & $\mathrm{Al}_{2} \mathrm{Si}_{2} \mathrm{O}_{5}(\mathrm{OH})_{4}$ & $\checkmark$ \\
\hline Monazite & $(\mathrm{Ce}, \mathrm{La}, \mathrm{Nd}, \mathrm{Th}) \mathrm{PO}_{4}$ & $\checkmark$ \\
\hline$x x x$ & \multicolumn{2}{|l|}{$20-50$ mass $\%$} \\
\hline$x x$ & \multicolumn{2}{|l|}{$5-20$ mass $\%$} \\
\hline$\checkmark$ & \multicolumn{2}{|l|}{ observed by SEM } \\
\hline
\end{tabular}

Apatite is the dominant P-bearing mineral, although some crandalite, an Al-bearing apatite is also present but in trace quantities [13]. The sedimentary phosphate ore ratio of quartz to apatite was on average 86:14. Master composite sample of the sedimentary phosphate ore submitted for apatite liberation characteristics is shown in Figure 5.

The apatite was $>90$ liberated in the $-425+250$ um fraction, and $-70 \%$ in the $-850+425$ um fraction. The $-2.35 m m+850 u m$ fraction showed poor liberation, with only $2 \%$ of apatite occurring as liberated particles [13].

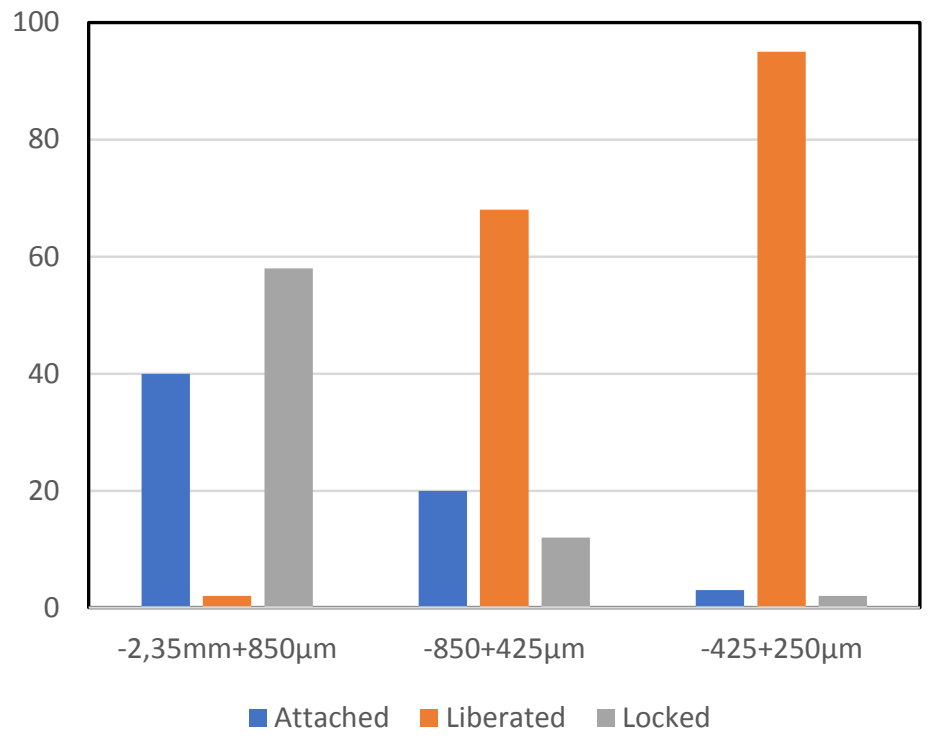

Fig.5: Liberation characteristics of apatite.

In summary, the major minerals present are quartz and apatite. According to [13], there are fine grained cement matrix with variable composition, often showing the presence of $\mathrm{Al}$ and apatite peloids with a more homogenous composition. Quartz however showed a bimodal grain size distribution, with coarse grains occurring as well rounded to sub-rounded particles and finer quartz as angular to sub-rounded.The mineralogical findings show that the beneficiation process of the sedimentary phosphate ore will be challenging, with the ore consisting primarily of the quartz $(86 \%)$ which must be rejected from apatite $(14 \%)$.

\section{H. Froth flotation results}

Froth flotation is used to separate quartz (tails) from apatite (concentrate). The primary objective is to produce a marketable phosphate concentrate containing $+30 \% \mathrm{P}_{2} \mathrm{O}_{5}$ grade with $\sim 10 \%$ $\mathrm{SiO}_{2}$ at a reasonable $+65 \% \mathrm{P}_{2} \mathrm{O}_{5}$ recovery.

Bench scale flotation results showed the following:

Coarse flotation (300/212um): Both tap and pit water tests could possibly achieve a product grade of 31,5-33,5\% $\mathrm{P}_{2} \mathrm{O}_{5}$ at between $81,6-92,8 \% \mathrm{P}_{2} \mathrm{O}_{5}$ flotation recoveries.

Fines flotation (212/20um): Tap and pit water tests could possibly achieve a product grade of $27,9 \%$ and $29,95 \% \mathrm{P}_{2} \mathrm{O}_{5}$ respectively. The flotation recovery ranged between $69 \%-76 \%$ $\mathrm{P}_{2} \mathrm{O}_{5}$. 
The flotation results using pit and tap water on different flotation feed sizes and reagent dosages looks favorably interesting. However, more tests to optimize amongst others the reagents dosages, flotation stages and reagents conditioning are further required.

The flotation results are expected to be viewed holistically. It is well documented however that flotation systems can be complex and consist of many interrelating variables. Klimpel (1995) cited in [14] explained the flotation system as the following major categories (1) Chemistry components which includes collectors, depressants, frothers, $\mathrm{pH}$ adjusters, and other reagents needed in the flotation systems, (2) Equipment components which includes the type of flotation device, flotation cell size, flotation circuit configuration and other parameters particular to specific flotation machines and (3) Operation components which includes mineralogy of feed ore, particle size, pulp density, feed rate, and temperature [14].

\section{CONCLUSION}

There were slightly higher concentrations of Sodium $(\mathrm{Na})$ and Chlorine $(\mathrm{Cl})$ on the pit water sample as expected when compared to tap water. This could be as results of the pit water being the actual seepage of the ground water. Previous studies have shown $\mathrm{NaCl}$ to have the tendency of depressing flotation and leading to inefficiencies. Pit water samples herein analyzed could be considered to be moderately hard which is economically positive in terms of the required interventions.

Major minerals present in the sedimentary phosphate ore are primarily quartz and apatite. There is a negative correlation between apatite liberation and size distribution.

The bench scale laboratory flotation results using the pit and tap water using different reagent dosages for both fines and coarse float feed fractions did not show significant differences. The results do not necessary rule out the possible need for pit water quality intervention prior to flotation. In other operations, examples of such interventions include amongst others introduction of a flocculation or coagulation system or simply a filtration system. The

It can be surmised that the data herein analyzed shows that impact of mining pit water has not been detrimental to flotation response of the sedimentary phosphate ore. It is however recommended that further tests be conducted to ascertain the preliminary findings.

\section{ACKNOWLEDGMENT}

The author is indebted to the sedimentary phosphate mine (South Africa, Western Cape) and Mintek for the actual test-work and results analysis.

The authors wish to acknowledge University of Johannesburg (Department of Metallurgy) for support of this project.

\section{REFERENCES}

[1] E. Muzenda, "An investigation into the effect of water quality on flotation performance.," World Academy of Science, Engineering and Technology, vol. 45, 2010.
[2] A. Alsafasfeh and L. Alagha, "Recovery of Phosphate Minerals from Plant Tailings Using Direct Froth Flotation.," Minerals, vol. 7, no. 8, p. $145,2017$. https://doi.org/10.3390/min7080145

[3] B. Wills and T. Napier-Munn, "Wills'Mineral Processing Technology," 2006.

[4] N. Sheni, K. Corin and J. Wiese, "Considering the effect of pulp chemistry during flotation on froth stability.," Minerals Engineering, vol. 116, pp. 15-23, 2018. https://doi.org/10.1016/j.mineng.2017.11.002

[5] A. Rusydi, "Correlation between conductivity and total dissolved solid in various type of water: A review.," IOP Conference Series: Earth and Environmental Science, vol. 118, no. No. 1, p. 012019, February 2018. https://doi.org/10.1088/1755-1315/118/1/012019

[6] B. Bosman, P. Wilson and E. Ontermaa, "Understanding water quality parameters for citrus irrigation and drainage systems," Univ. of Florida IFAS Extension, 2002.

[7] Who, U.N.A.I.D.S and Unicef, "TOWARDS UNIVERSAL ACCESS: Scaling up priority HIV/AIDS interventions in the health sector.," 2009.

[8] J. Cotruvo, "Hardness in Drinking Water, Background Document for Development of WHO Guidelines for Drinking Water Quality.," World Health Organization., 2011.

[9] J. Sherrad, D. Moore and T. Dillaha, "Total dissolved solids: determination, sources, effects, and removal," The Journal of Environmental Education, vol. 18, no. 2, pp. 19-24, 1987. https://doi.org/10.1080/00958964.1987.9943484

[10] M. Deng, Q. Liu and Z. Xu, "Water in Processing," Society for Mining, Metallurgy and Exploration, pp. 225-230, 2012.

[11] J. Mullaney, D. Lorenz and A. Arnston, Chloride in groundwater and surface water in areas underlain by the glacial aquifer system, northern United States, Reston, VA: US Geological Survey, 2009, p. 41. https://doi.org/10.3133/sir20095086

[12] S. Castro and J. Laskowski, "Froth flotation in saline water," KONA Powder and Particle Journal, vol. 29, pp. 4-15, 2011. https://doi.org/10.14356/kona.2011005

[13] W. Clark., "Internal report, Project MPC. 1-1," Unpublished, Johannesburg, 2004.

[14] S. Kawatra and J. Carlson, "Beneficiation of phosphate ore," Society for Mining, Metallurgy, and Exploration, pp. 20-22, 2013. 